\title{
FUNGSI KOGNITIF DENGAN KUALITAS HIDUP PADA LANSIA
}

\author{
Maria Manungkalit ${ }^{1}$, Ni Putu Wulan Purnama Sari ${ }^{2}$, Ninda Ayu Prabasari N. ${ }^{3}$ \\ Fakultas Keperawatan Universitas Katolik Widya Mandala Surabaya \\ Jl. Raya Kalisari Selatan no.1, Laguna, Pakuwon City, Surabaya, Indonesia \\ maria-manungkalit@ukwms.ac.id
}

\begin{abstract}
Abstrak
Seiring dengan bertambahnya usia yang menjadi tua, banyak kemunduran yang akan dialaminya salah satu adalah fungsi kognitif. Fungsi kerja otak dalam proses mengingat atau mengembalikan memori atau daya ingat merupakan bagian dalam kerja fungsi kognitif. Apabila fungsi kerja tersebut tidak dapat berfungsi maksimal maka akan mempengaruhi aktivitas atau kegiatan sehari-hari yang akan berdampak pada kualitas hidup lansia. Tujuan penelitian ini adalah menjelaskan hubungan fungsi kognitif dengan kualitas hidup lansia. Rancangan penelitian ini menggunakan pendekatan cross sectional. Populasi yang digunakan dalam penelitian ini adalah lansia yang tinggal di salah satu panti werdha di Surabaya yang berjumlah 150 orang. Jumlah sampel yang didapat berdasarkan kriteria inklusi dan eksklusi dalam penelitian ini sebanyak 145 responden. Alat ukur yang digunakan pada variabel independen fungsi kognitif adalah kuesioner Mini Mental State Exam (MMSE) sedangkan variabel dependen kualitas hidup adalah Older People Quality of Life (OPQOL). Hasil didapat sebagian besar lansia memiliki fungsi kognitif normal dengan kualitas hidup mayoritas cukup. Dilakukan uji analisa menggunakan Spearman's Rho $(\alpha<0,05)$ dan didapat hasil ada hubungan fungsi kognitif dengan kualitas hidup lansia dengan nilai $\mathrm{p}$ value 0.008 . Proses menua mengalami penurunan atau kemunduran fungsi kognitif dan akan berdampak terhadap kualitas hidupnya.
\end{abstract}

Kata kunci: Fungsi Kognitif, Kualitas Hidup, Lansia

\begin{abstract}
As age increases, various body deteriorioration will follow, one of them is cognitive function. The brain function of memory recall or remembering something is part of cognitive function. If this function weaken, daily activities will be disturbed and may have impacts on quality of life. This study aimed to analyze the correlation between cognitive function and quality of life in elderly. This was a cross-sectional design. Population was all elderly living in a private nursing home in Surabaya $(N=150)$. Based on sample's selection criteria, there were 145 elderly participated as respondents. Instruments used were Mini Mental State Exam (MMSE) for measuring cognitive function, and Older People Quality of Life (OPQOL) for measuring quality of life in elderly. Most respondents had normal cognitive function, but their quality of life was mostly sufficient. Statistical analysis by Spearman's Rho correlation test showed that cognitive function was significantly correlated with quality of life in elderly ( $p=0.008)$. The aging process has impact on cognitive function deterioration which resulted in a decrease in elderly's quality of life.
\end{abstract}

Keywords: cognitive function, elderly, quality of life

\section{PENDAHULUAN}

Setiap manusia selama berlangsungnya proses kehidupan akan menghadapi penuaan atau menjadi tua karena hal tersebut merupakan suatu kondisi yang tidak dapat ditolak atau diubah oleh siapapun. Proses menua yang dihadapi manusia merupakan proses yang alamiah. Kementerian Kesehatan (Kemenkes RI, 2016), menyatakan bahwa yang dikatakan lanjut usia (lansia) adalah seorang individu yang memasuki 60 tahun ke atas atau dapat dikategorikan menjadi dua kategori lansia yaitu usia lanjut 60-69 tahun dan usia lanjut dengan

Corresponding author:

Maria Manungkalit, dkk

maria-manungkalit@ukwms.ac.id 
resiko tinggi diatas 70 tahun atau lebih dengan gangguan kesehatannya. Pada umumnya, masalah kesehatan yang dialami lansia adalah mengalami kemunduran berbagai fungsi organ tubuh sehingga akan banyak mengalami perubahan anatomis dan fisiologis dimana salah satunya organ otak (Bandiyah, 2015). Perubahan yang tampak pada lansia adalah ditemukannya masalah fungsi kerja otak menurun atau biasa disebut menurunnya fungsi kognitif. Menurunnya fungsi kognitif pada lansia disebabkan oleh berkurangnya jumlah sel anatomis, terpaparnya radikal bebas, terpaparnya polusi, menurunnya asupan makanan, dan berkurangnya aktivitas sehingga hal tersebut menyebabkan perubahan strukur anatomi dan fisiologis menuju usia menua salah satunya adalah otak. Gejala yang sering tampak pada dampak penurunan fungsi kognitif adalah mudah lupa dan merupakan gejala ringan. Gejala ini ditemukan pada usia 50-59 persen dan diprediksi sebanyak 39\% dari jumlah total lansia dan akan bertambah sampai 85 persen ketika menginjak usia lebih dari 80 tahun. Gangguan fungsi kognitif merupakan kemunduran daya ingat dan memori yang dapat mempengaruhi rutinitas aktifitas lansia. Contoh sederhana adalah gejala muda lupa yang dialami lansia dan bila dibiarkan akan menjadi parah atau gejala berat yang ditandai dengan lansia mengalami kepikunan. Dikutip dalam penelitian Aini \& Puspitasari, 2016, Stanley dan Berae, 2007 menyatakan bahwa gejala yang dapat ditimbulkan pada gangguan kognitif dapat mengganggu kualitas hidup lansia seperti stres, merasa khawatir akan pengaruh gangguan fungsi kognitif diamana lansia akan merasakan membutuhkan seorang tenaga kesehatan dalam membantu melakukan aktivitasnya sehingga kekawatiran tersebut dapat menyebabkan penurunan kualitas hidup.

Akdag, Telci, \& Cavlak, 2013 menyatakan dalam hasil penelitian bahwa kognitif dapat mempengaruhi kualitas hidup lansia karena kerusakan pada kognitif dapat menurunkan kualitas hidup.

Pertumbuhan jumlah lansia didunia meningkat sangat cepat. Diperkirakan tahun 2050 peningkatan jumlah lansia mencapai dua miliar atau meningkat 22\%. Negara-negara berkembang memperlihatkan adanya peningkatan jumlah lansia jauh lebih cepat dari Negara-negara maju. Menurut Kementrian Kesehatan RI, tahun 2020 data menunjukkan jumlah lansia di Indonesia sejumlah 27,1 juta atau $10 \%$ dari total jumlah penduduk. Peningkatan tersebut akan bertambah pula dari tahun ketahun dimana tahun 2025 di prediksikan terjadi peningkatan hingga 33.7 persen atau 11.8 persen dari total jumlah penduduk. Dampak dari pertambahan jumlah tersebut maka masalah kesehatan lansia sudah jelas yaitu terjadi kemunduran fungsi kognitif yang juga akan berdampak pada kualitas hidup lansia. Bertambahnya jumlah lansia dari tahun ke tahun akan berdampak terhadap lansia pula yaitu meningkatnya ketergantungan lansia terhadap orang lain karena lansia mengalami keterbatasan atau ketidakmampuan dalam melakukan aktivitasnya sehingga mempengaruhi kualitas hidupnya (Yuliati et al., 2014). Dengan adanya peningkatan tersebut maka tantangan terhadap masalah kesehatan lansia juga akan terganggu, untuk itu perlu dipersiapkan seorang lansia yang memliki kualitas hidup yang baik, sehat, dan mandiri.

Pertambahan umur merupakan sesuatu yang alami dan patut disyukuri. Dalam pertambahannya menuju menua, yang akan dialami manusia adalah berubahnya secara fisik, kognitif, dan psikososialnya. Namun, dengan pertambahan usia tersebut, pada saat menua permasalahan kesehatan akan dihadapi lansia yakni mengalami kemunduran fungsi organ tubuh dimana salah satunya adalah otak. Kemunduran fungsi otak dapat terlihat jelas pada lansia dimana lansia akan mengalami gejala ringan mudah lupa dan jika gejala semakin parah lansia akan mengalami demensia yang merupakan manifestasi klinis yang berat (Wreksoatmodjo, 2014). Penurunan fungsi kognitif akan mempengaruhi kegiatan aktivitas sehari-hari lansia menjadi terganggu bahkan bila berlangsung lama akan mengakibatkan menurunnya kualitas hidup lansia.

Kualitas hidup lansia merupakan persepsi tentang kondisi lanjut usia yang mencerminkan kehidupan dalam memaknai usia dan bersiap meninggal dengan damai (Kathiravellu, 2016). Karakteristik lansia dengan kualitas hidup yang baik adalah memiliki kondisi fungsi organ tubuh yang optimal dalam melakukan kegiatannya seharihari secara mandiri dan fungsi kognitifnya masih baik. Selain itu, karakteristik yang lainnya adalah mempunyai kepuasan terhadap hidupnya, sejahtera dalam menjalin hubungan 
sosial dengan orang lain, dan merasa nyaman dengan kondisi sekitar atau lingkungannya.

Akdag et al., 2013 berpendapat bahwa kognitif dapat mempengaruhi kualitas hidup lansia yang disebabkan oleh kerusakan pada kognitif sehingga dapat menurunkan kualitas hidup lansia. Hal ini disebakan oleh bertambahnya usia dimana adanya perubahan pada fungsi otak yang dialami lansia yaitu kesulitan dalam mengingat kembali atau muda lupa (gejala ringan) (Agustia, S., Sabrian, F. \& Woferst, 2014). Bila tidak ditangani dengan baik masalah gejala kognitif ringan maka bisa berlanjut menjadi gejala berat yaitu gangguan demensia vascular ataupun Alzheimer Disease (Muzamil et al., 2014). Lansia yang mengalami demensia akan sering lupa dalam pemenuhan kebutuhan dasarnya seperti makan, minum, eliminasi, dan bahkan lupa terhadap lingkungannya. Studi dikomunitas didapatkan prevalansi gangguan kognitif lansia terjadi sebesar 17-34\% (Pandean \& Surachmanto, 2016).

Murtiyani, Hartono, Suidah, \& Pangertika, 2017 menyatakan bahwa solusi untuk mengatasi masalah gangguan kognitif pada lansia adalah dengan meningkatkan fungsi kognitif pada lanjut usia. Beberapa kegiatan yang bisa diberikan kepada lansia yang mengalami gangguan kognitif yaitu latihan meningkatkan daya ingat, terapi manajemen stress, terapi kemampuan social, terapi komunikasi antar lansia serta terapi preilaku. Tujuan kegiatan ini diharapkan dapat meningkatkan kualitas hidup lansia sehingga dapat mengurangi masalah kesehatan yang sering dijumpai pada lansia salah satunya gangguan fungsi kognitif.

Berdasarkan uraian latar belakang diatas, maka peneliti tertarik untuk melakukan penelitian tentang hubungan fungsi kognitif dengan kualitas hidup pada lansia.

\section{METODE PENELITIAN}

Dalam riset ini, design yang digunakan adalah deskriptif analitik dengan pendekatan cross sectional. Populasi yang digunakan dalam penelitian ini adalah lansia yang tinggal di Panti Werdha St. Yosef Surabaya yang berjumlah 150 orang. Sampel yang digunakan adalah lansia yang tinggal di panti dan masuk dalam kriteria inklusi yaitu minimal 60 tahun, mau berpartisipasi dan kooperatif, sedangkan yang tidak masuk dalam kriteria ini adalah responden yang menolak mengisi form informed concent dan responden yang mempunyai gangguan disorientasi.

Teknik sampling yang digunakan dalam penelitian ini adalah Non probability sampling jenis total sampling (Nursalam, 2016). Jumlah sampel yang didapat berdasarkan kriteria inklusi dan eksklusi dalam penelitian ini sebanyak 145 orang. Alat ukur yang digunakan pada variabel independen fungsi kognitif adalah kuesioner Mini Mental State Exam (MMSE) (Folstein, et al., 1975) dan variabel dependen kualitas hidup adalah Older People Quality of Life (OPQOL) (Gabriel \& Bowling, 2004). Instrumen Mini Mental State Exam (MMSE) [Folstein, et al., 1975) dan OPQOL digunakan untuk mengumpulkan data fungsi kognitif dan QOL masing-masing. Butir 35 OPQOL tentang pentingnya acara budaya / keagamaan / festival bagi kualitas hidup lansia tidak valid, sehingga dikeluarkan dari instrumen.

Pengambilan data calon responden dimulai dari permohonan perijinan untuk melakukan penelitian dipanti werdha kepada kepala pantinya. Setelah diberi ijin, selanjutnya peneliti melakukan pendataan calon responden dan jika sudah terkumpul maka peneliti melakukan pendekatan kepada calon responden dengan mengatur pertemuan dengan jadwal panti berkumpul bersama setiap hari jam 8-10 pagi. Bagi responden yang tidak bisa menghadiri pertemuan di jam tersebut, peneliti melakukan pendekatan kepada responden dengan mengunjungi kamarnya masing-masing sesuai data yang sudah didapatkan. Calon responden akan diminta persetujuan melalui pengisian informed concent untuk dijadikan responden. Selanjutnya, peneliti memberikan kuesioner MMSE dan OPQOL untuk diisi oleh responden dan bila sudah setelah kuesioner lengkap, peneliti akan melakukan proses mengedit, menilai, membuat tabulasi, dan analisa terhadap hasil yang didapat. Data yang ada selanjutnya dianalisis memakai uji korelasi Spearman's Rho $(\alpha<0,05)$. 


\section{HASIL}

Tabel 1. Data Demografi Responden

\begin{tabular}{|c|c|c|c|c|}
\hline No. & Variabel & Kategori & $\mathbf{N}$ & $\%$ \\
\hline \multirow[t]{4}{*}{1.} & Usia & Pertengahan (45-59) & 9 & 6.20 \\
\hline & & Elderly (60-74) & 65 & 44.82 \\
\hline & & Old (75-90) & 68 & 46.89 \\
\hline & & Very Old $(>90)$ & 3 & 2.06 \\
\hline \multirow[t]{2}{*}{2.} & Gender & Pria & 71 & 48.96 \\
\hline & & Wanita & 74 & 51.03 \\
\hline \multirow[t]{5}{*}{3.} & Pendidikan & SD & 29 & 20.00 \\
\hline & & Smp & 50 & 34.48 \\
\hline & & Sma & 44 & 30.34 \\
\hline & & PT & 19 & 11.03 \\
\hline & & $\mathrm{TS}$ & 3 & 2.06 \\
\hline \multirow[t]{4}{*}{4.} & Suku & Jawa & 55 & 37.93 \\
\hline & & Madura & 10 & 6.89 \\
\hline & & Cina & 76 & 52.41 \\
\hline & & Lainnya & 4 & 2.75 \\
\hline \multirow[t]{4}{*}{5.} & Status Pernikahan & Single & 33 & 22.75 \\
\hline & & Menikah & 58 & 40 \\
\hline & & Cerai/Pisah & 9 & 6.20 \\
\hline & & Janda/Duda & 45 & 31.03 \\
\hline \multirow[t]{4}{*}{6.} & Orang Terdekat & Anak/Cucu & 77 & 53.10 \\
\hline & & Istri/Suami & 15 & 10.34 \\
\hline & & Saudara & 27 & 18.62 \\
\hline & & Teman & 26 & 17.93 \\
\hline \multirow[t]{4}{*}{7.} & Pekerjaan (Sebelum Masuk Panti) & Pensiun & 42 & 28.96 \\
\hline & & Tidak Bekerja & 36 & 17.93 \\
\hline & & Irt & 33 & 22.75 \\
\hline & & Paruh Waktu & 34 & 23.44 \\
\hline \multirow[t]{4}{*}{8.} & Penghasilan per Bulan sebelum & $<1.500 .000$ & 27 & 18.62 \\
\hline & masuk panti & $1.500 .000-3.000 .000$ & 34 & 23.44 \\
\hline & & $>1.500 .000$ & 8 & 5.51 \\
\hline & & Tidak Ada & 76 & 52.41 \\
\hline \multirow[t]{3}{*}{9} & Penyakit yang diderita & Penyakit Menular & 1 & 0.68 \\
\hline & & Tidak Menular & 38 & 26.20 \\
\hline & & Tidak Sakit & 106 & 73.10 \\
\hline \multirow[t]{3}{*}{10} & Jenis Obat yang diminum & Oad & 10 & 6.89 \\
\hline & & $\mathrm{Ht}$ & 27 & 18.62 \\
\hline & & Tidak Ada & 108 & 74.48 \\
\hline \multirow[t]{4}{*}{11.} & Hubungan dengan keluarga & Suami & 35 & 24.13 \\
\hline & & Istri & 37 & 25.51 \\
\hline & & Anak & 58 & 40 \\
\hline & & Teman & 15 & 10.34 \\
\hline \multirow[t]{5}{*}{12.} & Kunjungan Keluarga & 1 Bulan & 60 & 41.37 \\
\hline & & 2-3 X/Mgg & 40 & 27.58 \\
\hline & & Setiap Mgg & 24 & 16.55 \\
\hline & & 1 Tahun Sekali & 0 & 0 \\
\hline & & Tidak Pernah & 21 & 14.48 \\
\hline \multirow[t]{4}{*}{13.} & Lama di panti & $<1$ Tahun & 33 & 22.75 \\
\hline & & 1-3 Tahun & 59 & 4.68 \\
\hline & & 4-6 Tahun & 41 & 28.27 \\
\hline & & $>6$ Tahun & 12 & 8.27 \\
\hline
\end{tabular}

Tabel 1 menunjukkan bahwa mayoritas responden berdasarkan usia sejumlah 68 orang dengan kategori usia tua (old) dengan rentang 75-90 tahun, mayoritas perempuan sebanyak 74 orang, pendidikam sebagian besar adalah SMP sebanyak 50 orang, kebanyakan lansia sudah menikah sebanyak 58 orang, dimana sebagian besar orang terdekatnya adalah anak atau cucunya sebanyak 77 orang. Dari data juga didaptkan sebagian besar lansia adalah bekerja namun sudah pensiun sebanyak 
42 orang, dan kebanyakan responden mengatakan tidak sakit sebanyak 106 orang, kunjungan keluarga terhadap responden mayoritas setiap bulan dikunjungi sebanyak 60 responden dan sebagian besar responden lama tinggal dipanti selama 1-3 tahun.

Tabel 2 Data Khusus

\begin{tabular}{lllll}
\hline No. & Variabel & Kategori & n & \% \\
\hline 1 & Fungsi Kognitif & Normal & 84 & 57,94 \\
& & Gangguan Ringan & 42 & 28,96 \\
& & Gangguan Berat & 19 & 13,10 \\
2 & Kualitas Hidup & Rendah & 4 & 2,76 \\
& & Cukup & 112 & 77,24 \\
& & Tinggi & 29 & 20,00 \\
\hline
\end{tabular}

Berdasarkan tabel 2, pada fungsi kognitif didapatkan hasil sebanyak 84 orang responden dengan fungsi kognitif normal dan sebanyak 112 orang dengan responden kualitas hidup cukup.

Tabel 3 Hubungan Fungsi Kognitif Dengan Kualitas Hidup

\begin{tabular}{|c|c|c|c|c|}
\hline \multicolumn{5}{|c|}{ Correlations } \\
\hline & & & MMSE & QPQOL \\
\hline \multirow[t]{6}{*}{ Spearman's rho } & MMSE & $\begin{array}{l}\text { Correlation } \\
\text { Coefficient }\end{array}$ & 1.000 & .221 \\
\hline & & Sig. (2-tailed) & & .008 \\
\hline & & $N$ & 145 & 145 \\
\hline & QPQOL & $\begin{array}{l}\text { Correlation } \\
\text { Coefficient }\end{array}$ & .221 & 1.000 \\
\hline & & Sig. (2-tailed) & .008 & \\
\hline & & $N$ & 145 & 145 \\
\hline
\end{tabular}

Berdasarkan dari tabel 3 diatas didapatkan hasil uji statistik Spearmean's rho adalah nilai $\mathrm{p}=0.008$ artinya ada hubungan antara fungsi kognitif dengan kualitas hidup dengan mayoritas usia lansia 75-90 tahun.

\section{PEMBAHASAN}

Penelitian ini dilaksanakan di panti werdha yang merupakan rumah tempat memelihara dan merawat lansia dan orang jompo. Orang jompo diartikan bahwa sesorang yang sudah tua sekali, mengalami kelemahan fisik, tua renta, dan uzur. Tidak tampak perbedaan signifikan bila melihat dari data karateristik responden berdasarkan jenis kelamin karena memang di panti werdha lakilaki dan perempuan diterima tanpa melihat gendernya.

Hasil penelitian pada tabel 3 menunjukkan bahwa responden kebanyakan mempunyai fungsi kognitif yang normal sebanyak $57.94 \%$ dengan kualitas hidup cukup sebanyak 77.24\%. hasil uji Spearmean's rho diperoleh nilai $\mathrm{p}$ sebesar $0.008<\alpha(0.05)$ sehingga dapat disimpulkan ada hubungan yang bermakna antara fungsi kognitif dengan kualitas lansia di Panti Werdha St. Yosep Surabaya. Responden yang memiliki fungsi kognitif normal dalam penelitian ini dapat digambarkan bahwa memiliki kecendrungan kualitas hidup yang cukup. Hal ini seirama dengan hasil penelitian (Boru, 2020) yang berjudul hubungan penerimaan diri dengan kualitas hidup lansia di Panti Werdha Pangesti Kecamatan Lawang Kabupaten Malang didapatkan hasil bahwa mayoritas responden mempunyai kualitas hidup yang baik sebanyak 32 orang $(71,1 \%)$.

Banyak faktor yang mempengaruhi kualitas hidup lansia yakni kondisi fisik, kognitif, sosial serta lingkungan (Akdag et al., 2013). (Vaarama, 2009) juga menyatakan bahwa ada banyak faktor yang memengaruhi kualitas hidup lansia yakni bagaimana karakteristik fungsi sosial dan demografi contohnya umur, jenis kelamin, status pernikahan dan kedekatan dengan orang lain. Selain itu, terdapat beberapa variabel yang mendukung kualitas hidup pada lansia, di antaranya yaitu jenis kelamin, usia, status kesehatan, status perkawinan,lingkungan 
sekitar, masalah ekonomi, serta komunikasi dan hubungan sosial individu dengan orang lain. Lansia yang menyadari kondisi fungsionalnya berada pada kondisi yang masimal dan optimal adalah lansia yang dapat merasakan kualitas hidupnya baik dan menjalani hari-harinya diusia lanjut dengan memaknai, mencari kebahagiaan, dan merasa berguna serta berkualitas bagi dirinya dan orang lain (Sutikno, 2011). Pengelompokan usia yang didapat dari tabel 1 berdasarkan usia adalah mayoritas berusia 75-90 tahun sebanyak 68 dan tidak terlalu signifikan dengan usia 60-74 sebanyak 65 orang. Hal ini sejalan dengan (Suardana et al., 2014) yang menyatakan bahwa seseorang dalam usia tuanya merasakan mampu mengevaluasi hidupnya dengan lebih positif dibandikan ketika mereka masih muda sehingga persepsi yang positif ini mempengaruhi kualitas hidup lansia menjadi lebih baik pula.

Faktor lain yang didapat dari hasil penelitian ini adalah faktor pendidikan dimana hasil menunjukkan sebagian besar adalah SMP sebanyak 50 orang. Hasil ini didukung oleh (Nofitri, 2009) yang menyatakan bahwa seiring dengan adanya peningkatan dalam tingkat pendidikan maka akan meningkat pula kualitas hidup sesorang. Sesorang yang memiliki tingkat pendidikan yang baik maka akan lebih matur atau dewasa terhadap proses perubahan dalam dirinya sehingga dapat bersikap positif terhadap pengaruh dari luar dan lebih objektif juga terbuka untuk mau menerima informasi mengenai kesehatan di masa tuanya sehingga akan mempengaruhi kualitas hidup yang semakin baik. Selain itu, hasil penelitian juga membuktikan bahwa sebagian besar responden memiliki fungsi kognitif normal sebanyak 84 orang $(57.94 \%)$. Faktor pendidikan juga merupakan salah satu faktor pendukung dalam pengukuran fungsi kognitif. Pendidikan yang semakin tinggi diharapkan dapat menambah pengetahun dan wawasan serta pengalaman seseorang yang akan berdampak terhadap fungsi kognitif dan kualitas hidupnya.

Faktor lain yang dapat meningkatkan kualitas hidup yang baik yaitu status pernikahan. Riset ini didapatkan mayoritas lansia dengan status pernikahan menikah sebanyak 58 orang $(40 \%)$. Hal ini sejalan dengan Astuti, 2019 yang menyatakan bahwa status pernikahan merupakan faktor yang mempengaruhi kualitas hidup lansia dimana lansia dengan status menikah dan memiliki pasangan akan lebih cenderung dapat meningkatkan kualitas hidupnya.

Hasil penelitian ini menunjukkan bahwa ada hubungan yang bermakna antara fungsi kognitif dengan kualitas hidup lansia. Pernyataan ini sejalan dengan pendapat Gitahafas, 2011 yang menyatakan bahwa lansia yang memiliki gangguan fungsi kognitif mengalami penurunan kemampuan dalam berdaptasi dengan lingkungannya. Sehingga akan berpengaruh terhadap kemampuan aktivitas fisiknya sehingga mempengaruhi kualitas hidupnya (Aini \& Puspitasari, 2016). Berdasarkan hasil penelitiannya dapat disimpulkan bahwa faktor yang dapat menentukan kualitas hidup lansia dalam menjalani kegiatan rutin setiap harinya adalah lansia yang memeliki fungsi kognitif yang baik. Dengan demikian lansia yang mengalami gangguan atau penurunan fungsi fisiknya akan mempengaruhi fungsi memori atau daya ingatnya dan akan mengganggu aktivitas seharihari. Peneliti berpendapat bahwa lansia yang mempunyai fungsi kognitif yang baik maka akan sejalan dengan kualitas hidup yang baik dikarenakan adanya persepsi yang terbuka, mau menerima dan sikap yang positif terhadap proses perubahan dari pertambahan usianya.

\section{KESIMPULAN}

Berdasarkan hasil penelitian didapatkan bahwa ada hubungan fungsi kognitif dengan kualitas hidup lansia dengan $p$ value $0.008>0.05$ dan dimana mayoritas lansia memiliki fungsi kognitif yang normal dengan kualitas hidup sebagian besar adalah cukup. Dalam meningkatkan kualitas hidup lansia juga perlu membangun hubungan yang baik melalui komunikasi dengan keluarga, pasangan, teman sekitar, atau dapat mengikuti kegiatan yang diadakan dipanti dalam upaya meningkatkan fungsi kognitif. Dengan demikian, lansia diharapkan fungsi kognitif dan kualitas hidupnya jauh lebih baik dalam jangka panjang.

\section{DAFTAR PUSTAKA}

Agustia, S., Sabrian, F. \& Woferst, R. (2014). Hubungan Gaya Hidup Dengan Fungsi Kognitif Pada Lansia. Jurnal Online Mahasiswa (JOM) Bidang Ilmu 
Keperawatan, 1(2), 1-8.

Aini, D. N., \& Puspitasari, W. (2016). Hubungan Fungsi Kognitif Dengan Kualitas Hidup Pada Lansia Di Kelurahan Barusari Kecamatan Semarang Selatan. 7(1), 6-12.

Akdag, B., Telci, E. A., \& Cavlak, U. (2013). Factors Affecting Cognitive Function in Older Adults: A Turkish Sample. International Journal of Gerontology, 7, 137-141.

Astuti, A. D. (2019). Status Perkawinan Meningkatkan Kualitas Hidup Lansia Di Pstw Sinta Rangkang Tangkiling Kalimantan Tengah. Jurnal Keperawatan Dan Kesehatan Masyarakat Cendekia Utama, 8(1), 1-8.

Bandiyah, S. (2015). Lanjut Usia dan Keperawatan Gerontik. Nuha Medika.

Boru, Y. D. (2020). Hubungan Penerimaan Diri Terhadap Kualitas Hidup Lansia di Panti Werdha Pangesti Kecamatan Lawang Kabupaten Malang. In Skripsi. Universitas Tribhuwana Tunggadewi Malang.

Gitahafas. (2011). Kesehatan Otak.

Kathiravellu, S. C. K. (2016). Hubungan Status Depresi terhadap Kualitas Hidup Lansia di Wilayah Kerja Puskesmas Petang II Kabupaten Badung Bali Tahun 2015. Intisari Sains Medis, 6(1), 92-101.

Kementerian Kesehatan (Kemenkes) RI. (2016). Situasi Lanjut Usia (Lansia) di Indonesia.

Murtiyani, N., Hartono, A., Suidah, H., \& Pangertika, N. P. (2017). Fungsi kognitif dengan activities of daily living (adl) pada lansia. Hasil Penelitian Dan Pengabdian Masyarakat Seri Ke-1 Tahun, 235-248.

Muzamil, M. S., Afriwardi, \& Martini, R. D.
(2014). Hubungan Antara Tingkat Aktivitas Fisik dengan Fungsi Kognitif pada Usila di Kelurahan Jati Kecamatan Padang Timur. Jurnal Kesehatan Andalas, 3(2), 202-205.

Nofitri, N. F. M. (2009). Gambaran Kualitas Hidup Penduduk Dewasa pada Lima Wilayah di Jakarta. In Skripsi. Universitas Indonesia.

Nursalam. (2016). Metodologi Penelitian Ilmu Keperawatan:Pendekatan Praktis. Penerbit Salemba.

Pandean, G. V., \& Surachmanto, E. E. (2016). Hubungan hipertensi dengan fungsi kognitif di Poliklinik SMF Ilmu Penyakit Dalam RSUP Prof. Dr. R. D. Kandou Manado. Jurnal E-Clinic, 4(1).

Suardana, I. W., Saraswati, N. L. G. I., \& Fitriani, R. (2014). Status Kognitif dan Kualitas Hidup Lansia. In Skripsi. Politeknik Kesehatan Denpasar.

Sutikno, E. (2011). Hubungan Fungsi Keluargadengankualitas Hidup Lansia. Tesis.

Vaarama, M. (2009). Care-Related Quality of Life in Old Age. European Journal of Ageing, 6(2), 113-125. https://doi.org/10.1007/s10433-009-0115y

Wreksoatmodjo, B. R. (2014). Pengaruh Social Engagement terhadap Fungsi Kognitif Lanjut Usia di Jakarta. Cermin Dunia Kedokteran Journal, 41(3), 171-179.

Yuliati, A., Baroya, N., \& Ririanti, M. (2014). Perbedaan Kualitas Hidup Lansia yang Tinggal di Komunitas dengan di Pelayanan Sosial Lanjut Usia. E-Jurnal Pustaka Kesehatan, 2(1), 87-94. 